\title{
Smokeless tobacco extract inhibits proliferation and promotes apoptosis in oral mucous fibroblasts
}

\author{
LEI LI $^{1 *}$, XIAOQING ZHOU ${ }^{2}$ and YANRAN WANG ${ }^{1 *}$ \\ Departments of ${ }^{1}$ Stomatology and ${ }^{2}$ Oral and Maxillofacial Surgery, \\ Jining No. 1 People's Hospital, Jining, Shandong 272011, P.R. China
}

Received October 26, 2017; Accepted April 23, 2018

DOI: $10.3892 / \mathrm{ol} .2018 .9252$

\begin{abstract}
The consumption of smokeless tobacco extract (STE) is growing rapidly, and it has been implicated in several human diseases including diabetes, inflammation and a number of types of cancer. The toxicity of STE requires evaluation, as it is known to induce numerous public health issues. To investigate whether STE serves a role in cultured human oral mucosa fibroblasts (hOMFs), the present study examined HOMF morphology with inverted microscopy and immunofluorescence staining. The cell viability was measured with MTT assays, which detected the cell apoptosis rate via flow cytometry. The activities of reactive oxygen species (ROS), malondialdehyde (MDA), superoxide dismutase (SOD), and catalase (CAT) were measured via flow cytometry and commercial kits, subsequent to exposing the cells to various concentrations of STE. Reverse transcription quantitative polymerase chain reaction and western blot analyses were used to demonstrate that the mRNA and the protein expression levels of cell cycle-associated genes (cyclin-dependent kinase inhibitor 1 and cyclin D1), apoptosis-associated genes [B cell lymphoma 2 (Bcl-2) and Bcl-2-associatied X protein], tumor protein (p53), nuclear factor kappa light chain enhancer of activated $\mathrm{B}$ cells $(\mathrm{NF}-\kappa \mathrm{B})$-transcription factor (p65) signaling pathways, NF-E2-related factor 2 (Nrf2), heme oxygenase-1 (HO-1) and NAD(P)H: quinoneoxidoreductase1 (NQO1).The results indicated that the hOMF cells were positive for cytokeratin staining. STE induced G1-S cell cycle progression and cell apoptosis by regulating the cell cycle or apoptosis-associated proteins. STE treatment increased the concentrations of ROS and MDA, and decreased the concentrations of SOD
\end{abstract}

Correspondence to: Dr Xiaoqing Zhou, Department of Oral and Maxillofacial Surgery, Jining No. 1 People's Hospital, 6 Jiankang Road, Jining, Shandong 272011, P.R. China

E-mail: xiaoqingzhou225@163.com

*Contributed equally

Key words: smokeless tobacco extract, human oral mucosa fibroblast cells, tumor protein 53, nuclear factor kappa light chain enhancer of activated $\mathrm{B}$ cells, proliferation, apoptosis and CAT. STE unregulated phosphorylated-p53, NF-кB p65, Nrf2, HO-1, and NQO1 expression levels in the hOMF cells. The present study demonstrated that STE appears to promote oral disease.

\section{Introduction}

Smokeless tobacco (ST) has been used over centuries by large numbers of the global population. ST is a type of tobacco that is consumed orally or nasally, without burning the product $(1,2)$. ST products include moist snuff (finely ground or shredded tobacco applied to the gum or tongue), dry snuff (powdered tobacco inhaled nasally) and chewing or sucking tobacco (3). The consumption of ST products has been popular in several Asian countries including India and Pakistan, and in Africa, northern Europe and the United States of America $(1,4)$. The negative health consequences of ST remain controversial, although there is increasing evidence demonstrating that $>30$ compounds within ST exhibit cancer-inducing activities, including tobacco-specific nitrosamines (TSNAs), polycyclic aromatic hydrocarbons and formaldehyde $(5,6)$. Previous studies have demonstrated that the chemical components in ST were associated with an increased risk of a number of types of cancer, including oral, or oropharyngeal and esophageal cancer (7-10). N-nitrosonornicotine and 4-methyl-N-nitrosamino-1-(3-pyridyl)-1-butanoneare2principal human carcinogens of TSNAs $(11,12)$. These compounds were identified in the urine of ST users, and studies involving rats demonstrated that they may induce tumorigenesis in the pancreas, esophagus and oral cavity (13-15).

ST consumption has been identified to generate free radicals and result in increased oxidative stress, which destroys the homeostasis between pro- and antioxidants (16). Cellular DNA is damaged by reactive oxygen metabolites (ROMs), including superoxide anions, malondialdehyde and nitric oxide, and therefore an imbalance between pro- and antioxidants is directly associated with carcinogenesis $(16,17)$. The ability to eliminate ROMs using the antioxidant enzyme system is critically important for smokers (18). Active smokers and tobacco users have been demonstrated to exhibit the lowest levels of protective antioxidants in the general population, including superoxide dismutase (SOD), glutathione peroxidase and catalase (CAT) $(19,20)$. 
ST extracts (STE) are not only absorbed locally, but may also enter the systemic circulation $(21,22)$. Evidence has demonstrated the effects of STE in several biological processes, including inflammation, antioxidant defense and cell apoptosis $(23,24)$. Block et al (20) revealed the toxicity of chronic STE exposure for 184 days in male and female rats, where the animals experienced decreased body weight and a moderate toxic effect on a number of organs including the stomach, liver, kidneys, esophagus and lungs. The exact mechanisms of STE in human diseases remain unknown.

In order to evaluate the toxicity of STE on oral mucous fibroblasts, the present study first identified human oral mucosa fibroblasts (hOMF) cells by detecting cytokeratin expression. The effects of STE on the rates of proliferation and apoptosis of hOMF cells were then investigated by a series of experiments, including MTT assays, reverse transcription quantitative polymerase chain reaction (RT-qPCR) and western blot analysis. The present study analyzed the effect of the STE on the oxidative status of hOMF cells by measuring the production of reactive oxygen species (ROS), MDA, SOD and CAT following of exposure of the cells to a range of concentrations of $\operatorname{STE}(0,200,400$ and $800 \mu \mathrm{g} / \mathrm{ml})$. It was identified that the tumor protein 53 (p53) and nuclear factor kappa light chain enhancer of activated B cells (NF- $\mathrm{B}$ )-transcription factor p65 (p65) signaling pathways were involved in the effects of STE on cell proliferation and apoptosis.

\section{Materials and methods}

Cell culture and treatment. The hOMF cells and human normal fibroblast (NF) cells were purchased from Ai Yan Shanghai Biological Technology Co., Ltd (Shanghai, China). The cells were cultured in Dulbecco's modified Eagle's medium (DMEM; Invitrogen; Thermo Fisher Scientific, Inc., Waltham, MA, USA) with $10 \%$ fetal bovine serum (FBS; Invitrogen; Thermo Fisher Scientific, Inc.), $100 \mathrm{U} / \mathrm{ml}$ penicillin and $100 \mu \mathrm{g} / \mathrm{ml}$ streptomycin at $37^{\circ} \mathrm{C}$ in $95 \%$ humidity incubator with $5 \% \mathrm{CO}_{2}$. After culturing, the cellular morphology of the hOMF cells was observed and images were captured using fluorescence microscope (x200 magnification; Olympus Corporation, Tokyo, Japan) in four randomly selected fields of view.

The hOMF cells were digested, centrifuged in $500 \mathrm{x}$ g at $37^{\circ} \mathrm{C}$ for $5 \mathrm{~min}$ and seeded into plastic culture dishes $(35 \mathrm{~mm})$ with $5.0 \times 10^{5}$ cells/well for $48 \mathrm{~h}$. The cells were then treated with $\operatorname{STE}(0,200,400$ and $800 \mu \mathrm{g} / \mathrm{ml})$ for 24,48 and $72 \mathrm{~h}$ at $37^{\circ} \mathrm{C}$. The treated cells were then used for the subsequent experiments.

RT-qPCR assay. Total RNA was isolated with TRIzol ${ }^{\circledR}$ reagent (Life Technologies; Thermo Fisher Scientific, Inc.), in accordance with the manufacturer's protocol. The total RNA was reverse transcribed into the first-strand cDNAs via a RevertAid First Strand cDNA Synthesis kit (Thermo Fisher Scientific, Inc.), in accordance with the manufacturer's protocol. The thermocycler conditions were as follows: $85^{\circ} \mathrm{C}$ for $15 \mathrm{~min}, 4^{\circ} \mathrm{C}$ for $10 \mathrm{~min}$. The mRNA expression levels of the GAPDH and the target genes were evaluated with a qPCR assay using a SYBR GREEN PCR Master Mix (Applied
Biosystems; Thermo Fisher Scientific, Inc.) and an ABI 7500 Real-time PCR system (Applied Biosystems; Thermo Fisher Scientific, Inc.). The thermocycling conditions were as follows: $95^{\circ} \mathrm{C}$ for $10 \mathrm{~min}$, (denaturation: $95^{\circ} \mathrm{C}$ for $30 \mathrm{sec}$; annealing: $55^{\circ} \mathrm{C}$ for $30 \mathrm{sec}$; elongation: $72^{\circ} \mathrm{C}$ for $25 \mathrm{sec}$ ) for 30 cycles, extending: $72^{\circ} \mathrm{C}$ for $30 \mathrm{sec}$. The data was analyzed using the $2^{-\Delta \Delta \mathrm{Cq}}$ method (25). The relative mRNA expression levels were normalized to GAPDH. The primers for the target genes and GAPDH are summarized in Table I.

Western blot analysis. The hOMF cells were lysed with a radio immunoprecipitation assay (RIPA) buffer (Thermo Fisher Scientific, Inc.) supplemented with a Protease Inhibitor Cocktail (Thermo Fisher Scientific, Inc.). The protein concentrations were quantified with a BCA protein assay kit (Qcbio Science Technologies Co., Ltd., Shanghai, China). The proteins $(30 \mu \mathrm{g})$ were separated with polyacrylamide gel electrophoresis. The proteins were then transferred on to polyvinylidene fluoride membranes (EMD Millipore, Billerica, MA, USA), and TBST buffer containing 5\% skim milk was used to block the membranes at room temperature for $90 \mathrm{~min}$. The primary antibodies were incubated with the membranes overnight at $4^{\circ} \mathrm{C}$, followed by incubation with a horseradish peroxidase-conjugated secondary antibody (anti-mouse; cat. no., SC-2005; anti-rabbit, cat. no., SC-2004; dilution: 1:700, Santa Cruz Biotechnology, Inc., Dallas, TX, USA) at room temperature for $60 \mathrm{~min}$ and then incubation with a chemiluminescence substrate (Amersham; GE Healthcare, Chicago, IL, USA) at room temperature for $2 \mathrm{~min}$. The results were analyzed with an ECL system (Amersham; GE Healthcare). Images were captured by the LAS-3000 imaging system (FUJIFILM, Tokyo, Japan) and Multi Gauge Version 2.0 software (FUJIFILM). The primary antibodies used were as follows: Anti-GAPDH (cat. no., SC-47724, dilution, 1:2,000, Santa Cruz Biotechnology), anti-cyclin-dependent kinase inhibitor 1 (p21; dilution, 1:500, Abcam, Cambridge, MA, USA; cat. no., ab54562); anti-cyclin D1 (dilution, 1:1,000, Abcam; cat.no, ab134175); anti-B cell-lymphoma 2 (Bcl-2)-associated X protein (Bax; dilution, 1:1,000; Abcam; cat.no. ab32503); anti-Bcl-2 (dilution, 1:1,000; Abcam; cat. no., ab32124); anti-p53 (dilution, 1:100; Abcam; cat. no., ab28); anti-phosphorylated (p)-p53 (dilution, 1:500; Cell Signaling Technology, Inc., Danvers, MA, USA; cat. no., 9284); anti-NF-кB p65 (dilution, 1: 1,000, Abcam, cat. no., ab76026); anti-Nuclear factor (erythroid-derived 2)-like 2 (Nrf2; dilution, 1:1,000; Abcam; cat. no., ab76026); anti-Hemeoxygenase 1 (HO-1; dilution, 1:1,000; Abcam; cat. no., ab13248); and anti-NAD(P)H quinone dehydrogenase 1 (NQO1; dilution, 1:1,000; Abcam; cat. no., ab28947).

Cell viability assay. The treated hOMF cells were seeded in 96-well plates with $100 \mu \mathrm{l}$ DMEM medium (10\% FBS) at a density of $2 \times 10^{3}$ cells/well. They were cultured at $5 \% \mathrm{CO}_{2}$ for $48 \mathrm{~h}$ at $37^{\circ} \mathrm{C}$. A total of $20 \mu \mathrm{l} \mathrm{MTT}$ solution $(5 \mathrm{mg} / \mathrm{ml})$ was added into each well. The cells were then incubated for $4 \mathrm{~h}$ at $37^{\circ} \mathrm{C}$. A total of $200 \mu \mathrm{l}$ dimethyl sulfoxide was then added into each well for $10 \mathrm{~min}$ at room temperature, which dissolved the formazan product. The absorbance was measured at $490 \mathrm{~nm}$ with an Elx800 Reader (Bio-Tek Instruments Inc., Winooski, VT, USA). 
Table I. Primer sequences for reverse transcription quantitative polymerase chain reaction analysis.

Gene Primer sequences

$\begin{array}{ll}\text { GAPDH } & \text { Forward: 5'-TATGATGATATCAAGAGGGTA } \\ & \text { GT-3' } \\ & \text { Reverse: 5'-TGTATCCAAACTCATTGTCAT } \\ & \text { AC-3' } \\ \text { p21 } & \text { Forward: 5'-CTGGTGACTCTCAGGGTCGA } \\ & \text { A-3' } \\ & \text { Reverse: 5'-GGATTAGGGCTTCCTCTTGGA-3' }\end{array}$

Cyclin D1 Forward: 5'-GCTGCTCCTGGTGAACAAGC-3 Reverse: 5'-TTGCGTCTCAGCTCAGGGAC-3

Bax Forward: 5'-CAGCTCTGAGCAGATCATGAA GACA-3'

Reverse: 5'-GCCCATCTTCTTCCAGATGGTG AGC-3'

Bcl-2 Forward: 5'-ACTTGTGGCCCAGATAGGCAC CCAG-3'

Reverse: 5'-CGACTTCGCCGAGATGTCCAG CCAG-3'

p53 Forward: 5'-CAGCGTGATGATGGTAAGGA-3' Reverse: 5'-GCGTTGCTCTGATGGTGA-3'

NF-кB p65 Forward: 5'-ACGATCTGTTTCCCCTCATCT-3' Reverse: 5'-TGCTTCTCTCCCCAGGAATA-3'

Nrf2 Forward: 5'-TACTCCCAGGTTGCCCACA-3' Reverse: 5'-CATCTACAAACGGGAATGTCT GC-3'

HO-1 Forward: 5'-CACGCATATACCCGCTACCT-3' Reverse: 5'-AAGGCGGTCTTAGCCTCTTC-3'

NQO1 Forward: 5'-CATTCTGAAAGGCTGGTTT GA-3'

Reverse: 5'-CTAGCTTTGATCTGGTTGTCA G-3'

p21, cyclin-dependent kinase inhibitor 1; Bcl-2, B cell lymphoma 2; $\mathrm{Bax}, \mathrm{Bcl}-2$-associated $\mathrm{X}$ protein; NF- $\mathrm{B}$, nuclear factor kappa light chain enhancer of activated B cells, p65, transcription factor p65; p53, tumor protein 53; Nrf2, Nuclear factor (erythroid-derived 2)-like 2; HO-1, Hemeoxygenase 1; NQO1, NAD(P)H quinone dehydrogenase 1.

Immunofluorescence assay. The treated hOMF cells $\left(1 \times 10^{6}\right.$ cells $\left./ \mathrm{ml}\right)$ were fixed with $3.7 \%$ paraformaldehyde in PBS at room temperature for $20 \mathrm{~min}$. Triton X-100 (0.2\%) solutions in PBS were used for permeabilizing cells at room temperature for 10 min. 5\% BSA (Bovogen Biologicals, Keilor East, VIC, Australia) was used for blocking cells at room temperature for $20 \mathrm{~min}$. The cells were then incubated with cytokeratin antibody (cat. no. ab9377, dilution: 1:100; Abcam) overnight at $4^{\circ} \mathrm{C}$. The goat-anti-rabbit-Alexa 594-conjugated secondary antibody (cat. no. R37117, dilution: 1:6,000; Life Technologies; Thermo Fisher Scientific, Inc.) was then incubated with the treated coverslips for $1 \mathrm{~h}$ at room temperature. The treated coverslips were then incubated with DAPI (Life Technologies; Thermo Fisher Scientific, Inc.) for $10 \mathrm{~min}$ at room temperature. The images were obtained with a fluorescence microscope (x400 magnification), in four fields of view.

Flow cytometric analysis. A cell cycle analysis was performed with propidium iodide (PI; Sigma-Aldrich; Merck KGaA, Darmstadt, Germany) staining, as described previously $(26,27)$. The cells were collected and fixed in $70 \%$ (v/v) ethanol (cat. no. 5054.2; Carl Roth GmbH \& Co., KG, Karlsruhe, Germany) for $15 \mathrm{~min}$ at room temperature, then washed with PBS and suspended in a PI staining solution $(50 \mathrm{mg} / \mathrm{l}$; Biolegend, Inc., San Diego, CA, USA; cat. no. 421301) supplemented with $0.1 \%$ Triton X-100 and Ribonuclease A $(0.25 \mathrm{mg} / \mathrm{ml}$; Sigma-Aldrich; Merck KGaA). The cells were incubated at $37^{\circ} \mathrm{C}$ for $30 \mathrm{~min}$ and then the cell fluorescence was measured with a FACS Calibur flow cytometer (BD Biosciences, San Jose, CA, USA). The cell cycle analysis was performed with ModFit LT 2.0 software (Verity SoftwareHouse, Topsham, ME, USA).

The cell apoptosis assay was performed with an Annexin V-fluorescein isothiocyanate (FITC)/PI apoptosis detection kit (BestBio, Co., Shanghai, China) as described previously (28). The treated hOMF cells $\left(1 \times 10^{6}\right.$ cells $\left./ \mathrm{ml}\right)$ were re-suspended with a1X binding buffer $(100 \mu \mathrm{l})$, and then double-stained with $20 \mu \mathrm{g} / \mathrm{ml}$ Annexin V-FITC and $50 \mu \mathrm{g} / \mathrm{ml}$ PI for $15 \mathrm{~min}$ at room temperature. Cell apoptosis levels were then detected by flow cytometry with version 5.1 Cell Quest Pro software (BD FACSCalibur, San Jose, CA, USA).

Flow cytometry for ROS expression. ROS levels were detected with the membrane-permeable fluorescent probes 2',7'-dichlorofluorescin diacetate (DCFH-DA), as described previously (29). The treated hOMF cells $\left(1 \times 10^{6}\right.$ cells $\left./ \mathrm{ml}\right)$ were incubated with $2.5 \mathrm{mmol} / 1 \mathrm{DCFH}-\mathrm{DA}$ at $37^{\circ} \mathrm{C}$ for $25 \mathrm{~min}$. The cells were then washed with PBS, digested with $0.25 \%$ trypsin (Sigma-Aldrich; Merck KGaA), treated with DCFH-DA at $37^{\circ} \mathrm{C}$ for $25 \mathrm{~min}$, and finally detected by flow cytometry with version 5.1 Cell Quest Pro software. The fluorescence intensity was measured, and the average was calculated using at least 3 replicates.

SOD, MDA and CAT expression levels. SOD assay kit (cat, no. A001-3), MDA assay kit (cat, no. A003-1) and CAT assay kit (cat, no. A007-2) were purchased from Nanjing Jiancheng Bioengineering Institute (Nanjing, China). SOD, MDA and CAT activities $(30,31)$ were based on a colorimetric method and used in accordance with the manufacturer's protocol, as described previously (30-32). The colorimetric reactions were determined at 450 and $405 \mathrm{~nm}$ using UV-5800H spectrophotometer (Metash Instruments, Shanghai, China).

Statistical analysis. Statistical analyses were conducted with SPSS 19.0 software (SPSS, Inc., Chicago, IL, USA). The data are expressed as the mean \pm standard deviation. A one-way analysis of variance and Dunnett's post-hoc tests were performed to compare the differences between each group. $\mathrm{P}<0.05$ was considered to indicate a statistically significant difference.

\section{Results}

Morphology and cytokeratin of hOMF cells are identified. The results indicated that the hOMF cells exhibited a typical 

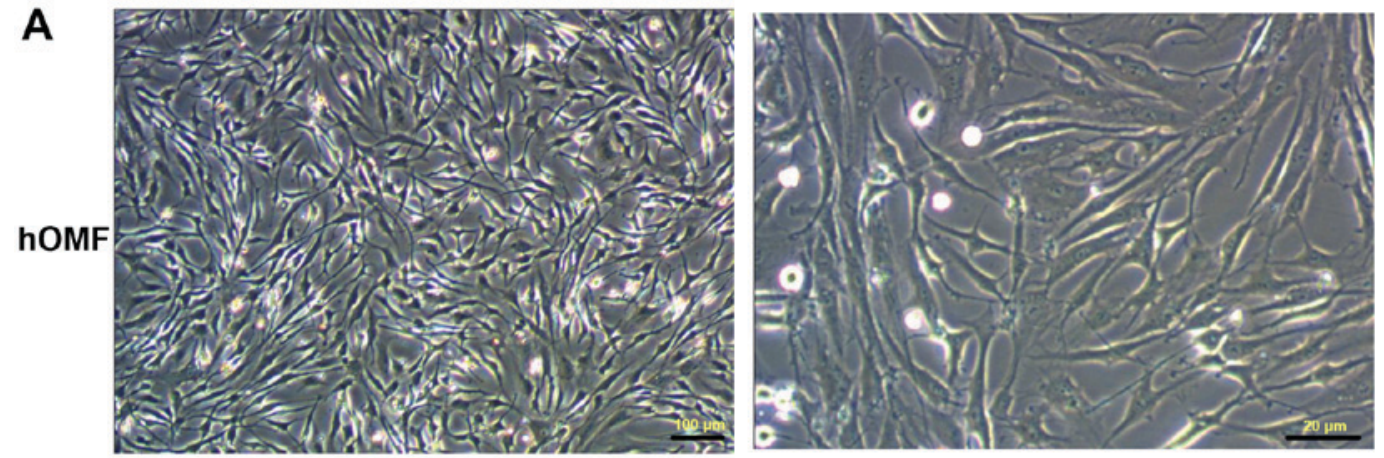

B

Cytokeratin
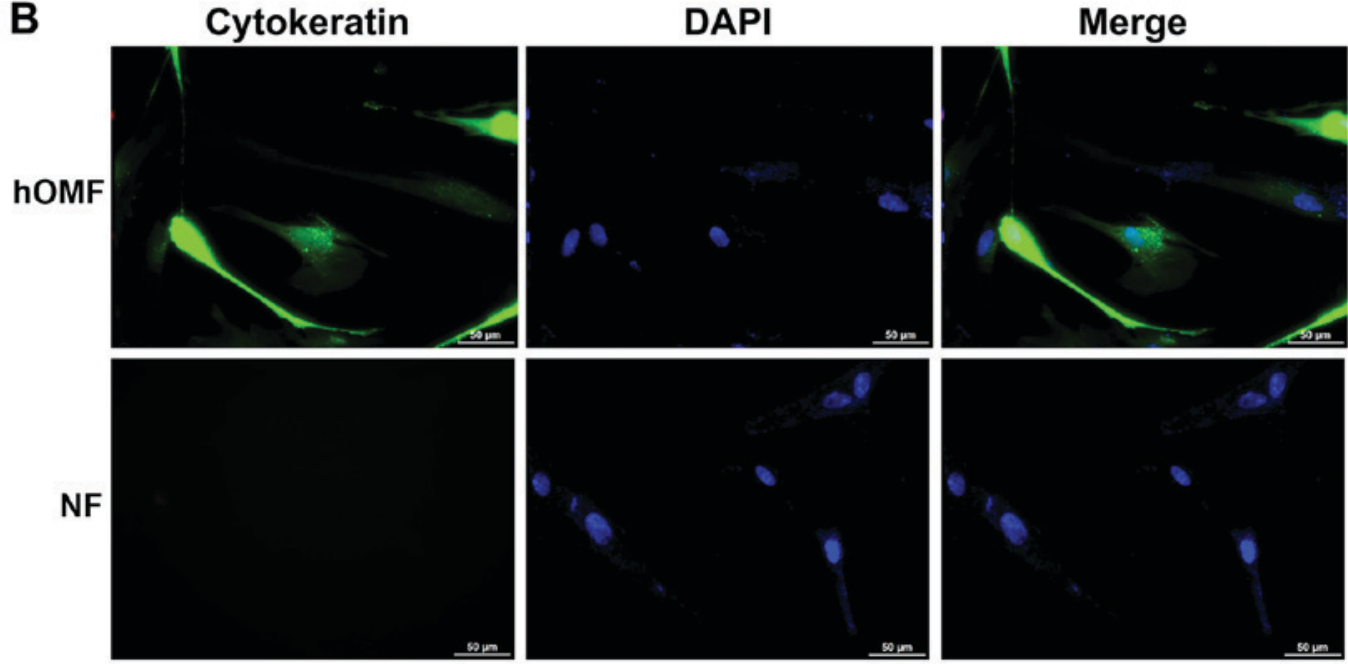

Figure 1. Morphology and cytokeratin of hOMF cells. (A) The cellular morphology of hOMF cells on the culture plates was observed and images were captured under the microscope after $48 \mathrm{~h}$ of cell culture. Left panel: Magnification, x100, Scale bar, $100 \mu \mathrm{m}$; Right panel: Magnification, x400, Scale bar, $20 \mu \mathrm{m}$. (B) Immunofluorescence staining indicated the expression level of cytokeratin in cultured hOMF and NF cells. The merged (Merge) image represents the superimposed images of cytokeratin in green and nuclei (DAPI) in blue. Scale bar, $50 \mu \mathrm{m}$. hOMF, human oral mucosa fibroblasts; NF, normal fibroblasts.

morphology (Fig. 1A). The cytokeratin level was detected with immunofluorescence staining in the hOMF and NF cells. It was identified that cytokeratin was expressed in the hOMF cells, but not in the NF cells (Fig. 1B).

Treatment with STE inhibits cell viability. The effects of STE on the proliferation of hOMF cells were determined by culturing the hOMF cells with specified concentrations of STE $(0,200,400$ or $800 \mu \mathrm{g} / \mathrm{ml})$ for 24,48 and $72 \mathrm{~h}$. MTT assays was performed to analyze the viability rate. It was identified that the STE inhibited the viability HOMF cells in dose- and a time-dependent manners (Fig. 2A).

Treatment with STE induces cycle progression of hOMF cells. The cell cycle distribution was additionally analyzed via flow cytometry with PI staining. The results revealed that the average percentages of cells in G1 phase were 67.03, 55.31, 49.69 and $46.50 \%$ at $0,200,400$ and $800 \mu \mathrm{g} / \mathrm{ml} \mathrm{STE}$ respectively. The average percentages of cells in the $\mathrm{S}$ phase were $11.37,29.50,33.38$ and $35.28 \%$ in the hOMF cells that were treated with 0, 200, 400 and $800 \mu \mathrm{g} / \mathrm{ml} \mathrm{STE}$, (Fig. 2B). In comparison with the control group (STE, $0 \mu \mathrm{g} / \mathrm{ml}$ ), STE treatment decreased the percentage of cells in the G1 phase, and increased the percentage of cells in the $S$ phase at 200 , 400 and $800 \mu \mathrm{g} / \mathrm{ml} \mathrm{STE} \mathrm{(Fig.} \mathrm{2C).} \mathrm{The} \mathrm{results} \mathrm{indicated} \mathrm{that}$ the G1-S cell cycle progression was induced by the STE in the hOMF cells. The mRNA and the protein expression levels of p21 and cyclin D1 were evaluated by RT-qPCR and western blot analysis. Fig. 2D indicates that STE treatment upregulated p21 expression and downregulated cyclin D1 expression in a concentration-dependent manner. It was also identified that the protein expression levels of p21 were increased and the protein expression levels of cyclin D1 were decreased in the STE treatment group (STE, $0 \mu \mathrm{g} / \mathrm{ml}$; Fig. 2E).

Treatment with STE promotes the apoptosis ability of hOMF cells. The present study analyzed the effects of the STE on apoptosis via flow cytometry (Fig. 3A), and the results indicated that the apoptotic indexes of the control $(0 \mu \mathrm{g} / \mathrm{ml})$ and STE treatment groups $(200,400$ and $800 \mu \mathrm{g} / \mathrm{ml})$ were $4.43,7.21,8.93$ and $16.58 \%$, respectively (Fig. 3B). The expression levels of the apoptosis-associated genes (Bax and Bcl-2) were then measured with RT-qPCR and western blot analysis. The results indicated that Bax expression levels were increased and the Bcl-2 levels were decreased in the hOMF cells treated with STE in a concentration-dependent manner (Fig. 3C and D).

STE increases the concentrations of ROS and MDA and decreases the concentrations of SOD and CAT. There have been several previous studies demonstrating that ROS serves 


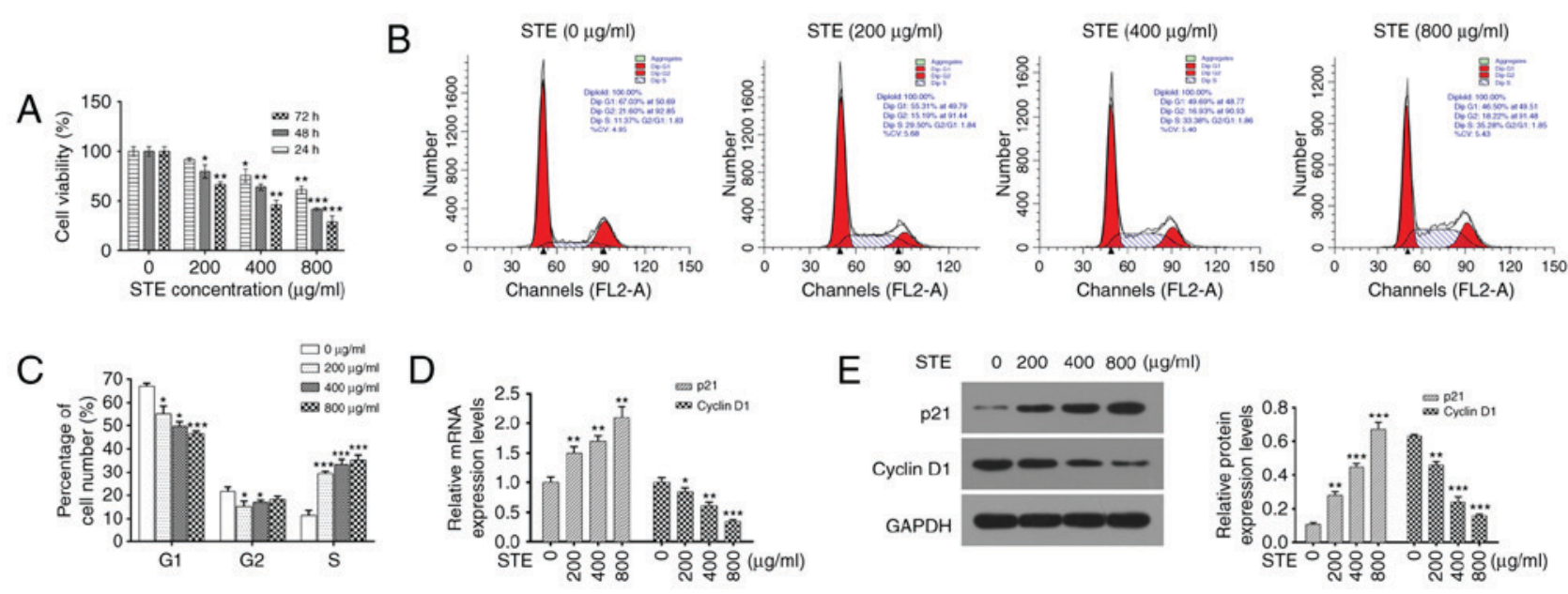

Figure 2. Treatment with STE inhibits viability and induces cycle progression of hOMF cells. (A) The viability rate was detected by MTT assay in hOMF cells cultured with specified concentrations $(0-800 \mu \mathrm{g} / \mathrm{ml})$ of STE for 24,48 and $72 \mathrm{~h}\left({ }^{*} \mathrm{P}<0.05,{ }^{* *} \mathrm{P}<0.01\right.$ and $\left.{ }^{* * *} \mathrm{P}<0.001 \mathrm{vs} .0 \mu \mathrm{g} / \mathrm{ml}\right)$. (B) The treated hOMF cells were collected at $48 \mathrm{~h}$, stained with propidium iodide and measured by flow cytometry. (C) The cell cycle distribution (G1, G2 and S phases) was measured and analyzed by in surviving cell populations ( $\left(\mathrm{P}<0.05\right.$ and $\left.{ }^{* * *} \mathrm{P}<0.001 \mathrm{vs} .0 \mu \mathrm{g} / \mathrm{ml}\right)$. (D) The mRNA expression levels of p21 and cyclin $\mathrm{D} 1 \mathrm{were}$ evaluated by reverse transcription-quantitative polymerase chain reaction $\left({ }^{*} \mathrm{P}<0.05,{ }^{* * *} \mathrm{P}<0.01\right.$ and $\left.{ }^{* * * *} \mathrm{P}<0.001 \mathrm{vs} .0 \mu \mathrm{g} / \mathrm{ml}\right)$. (E) Proteins were extracted from hOMF cells treated with different concentrations of STE. p21, cyclin D1 and GAPDH protein levels were detected by western blot analysis. GAPDH was used as a loading control. The relative protein expression levels of $\mathrm{p} 21$ and cyclin D1 were analyzed according to the protein grey values $\left.{ }^{* *} \mathrm{P}<0.01 \mathrm{and}{ }^{* * * *} \mathrm{P}<0.001 \mathrm{vs} .0 \mu \mathrm{g} / \mathrm{ml}\right)$. hOMF, human oral mucosa fibroblasts; STE, smokeless tobacco extracts; p21, cyclin-dependent kinase inhibitor 1.
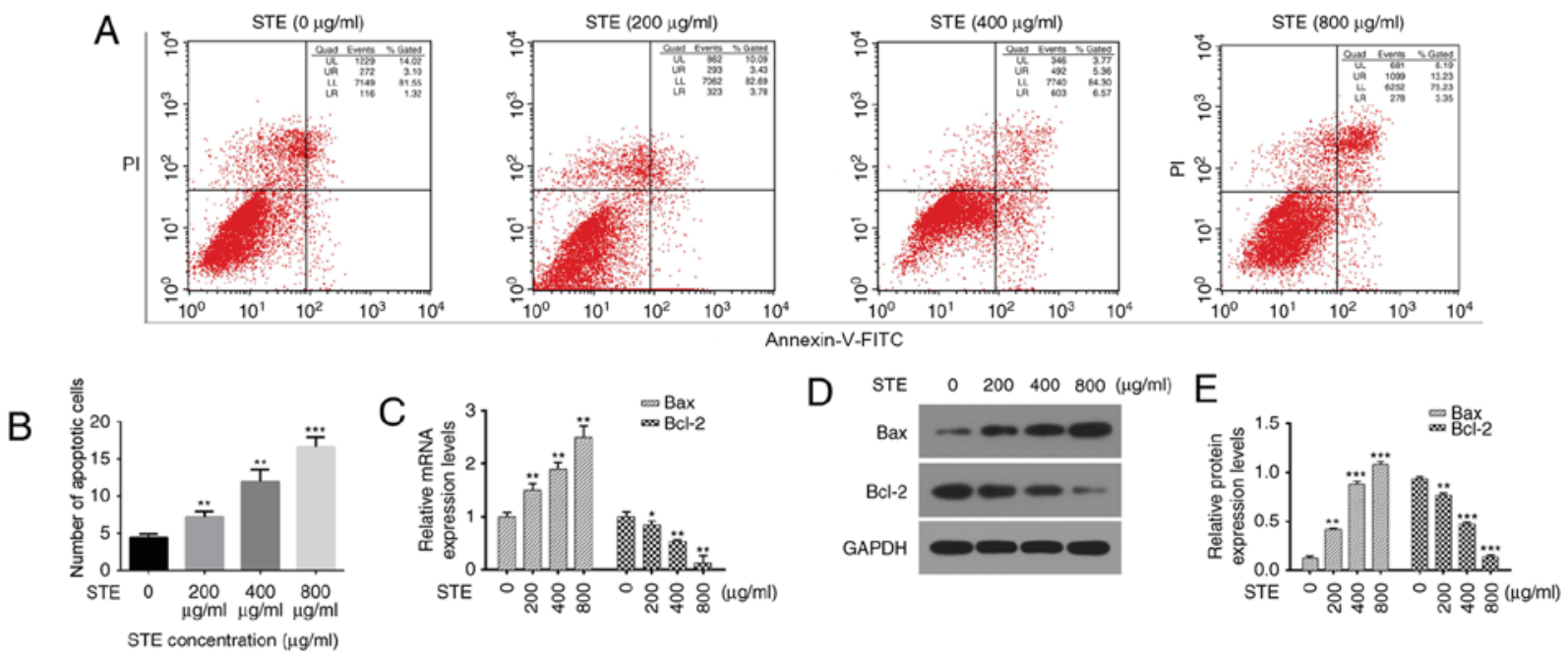

Figure 3. Treatment with STE promotes the apoptosis ability of hOMF cells. hOMF cells were treated with STE (0, 200, 400 and $800 \mu \mathrm{g} / \mathrm{ml})$ for $48 \mathrm{~h}$. (A) Flow cytometry with Annexin V-FITC/PI staining was performed to determine the apoptosis ratio of the treated hOMF cells. (B) The number of apoptotic cells in different groups was quantitatively analyzed $\left({ }^{* *} \mathrm{P}<0.01\right.$ and $\left.{ }^{* * *} \mathrm{P}<0.001 \mathrm{vs} .0 \mu \mathrm{g} / \mathrm{ml}\right)$. (C) Bax and Bcl-2 levels were detected by reverse transcription-quantitative polymerase chain reaction and normalized to GAPDH transcript levels ( ${ }^{*} \mathrm{P}<0.05$ and $\left.{ }^{* *} \mathrm{P}<0.01 \mathrm{vs} .0 \mu \mathrm{g} / \mathrm{ml}\right)$. (D) Bax, Bcl-2 and GAPDH protein levels were evaluated by western blot analysis using protein-specific antibodies and (E) quantified. The relative protein expression levels of Bax and Bcl-2 were analyzed according to the protein grey values $\left({ }^{* *} \mathrm{P}<0.01\right.$ and $\left.{ }^{* * *} \mathrm{P}<0.001 \mathrm{vs} .0 \mu \mathrm{g} / \mathrm{ml}\right)$. hOMF, human oral mucosa fibroblasts; STE, smokeless tobacco extracts; FITC, fluorescein isothiocyanate; PI, propidium iodide; Bcl-2, B cell lymphoma-2; Bax, Bcl-2-associated X protein.

a significant role in apoptosis induction under physiological and pathological conditions $(33,34)$. In the present study, the concentration of ROS was analyzed with a flow cytometer with DCFH-DA fluorescent probe in the hOMF cells treated with STE $(0,200,400$ and $800 \mu \mathrm{g} / \mathrm{ml})$ for $48 \mathrm{~h}$. The results indicated significant differences in the ROS levels among the STE treatment and the control (STE, $0 \mu \mathrm{g} / \mathrm{ml}$ ) groups (Fig. 4A). The concentration of ROS was significantly increased in the STE treatment groups (Fig. 4B). The results indicated that the SOD (Fig. 4C) and the CAT (Fig. 4D) activity levels were significantly decreased compared with $0 \mu \mathrm{g} / \mathrm{ml}$. The MDA activity level was significantly increased in the STE treatment group, compared with $0 \mu \mathrm{g} / \mathrm{ml}$ (Fig. 4E).

STE upregulates p-p53, NF- $\kappa B$ p $65, \mathrm{Nrf2}, \mathrm{HO}-1$, and NQOI expression levels in the hOMF cells. The regulatory effects of STE treatment were investigated by detecting the expression levels of p53, NF- $\kappa$ B p65, Nrf2, HO-1, and NQO1 via RT-qPCR and western blot analysis in hOMF cells treated with the STE $(0$, 200, 400 and $800 \mu \mathrm{g} / \mathrm{ml}$ ) for $48 \mathrm{~h}$. As demonstrated in Fig. 5A, the expression level of p-p53 was increased in the STE treatment group compared with $0 \mu \mathrm{g} / \mathrm{ml}$. The results also indicated 
A
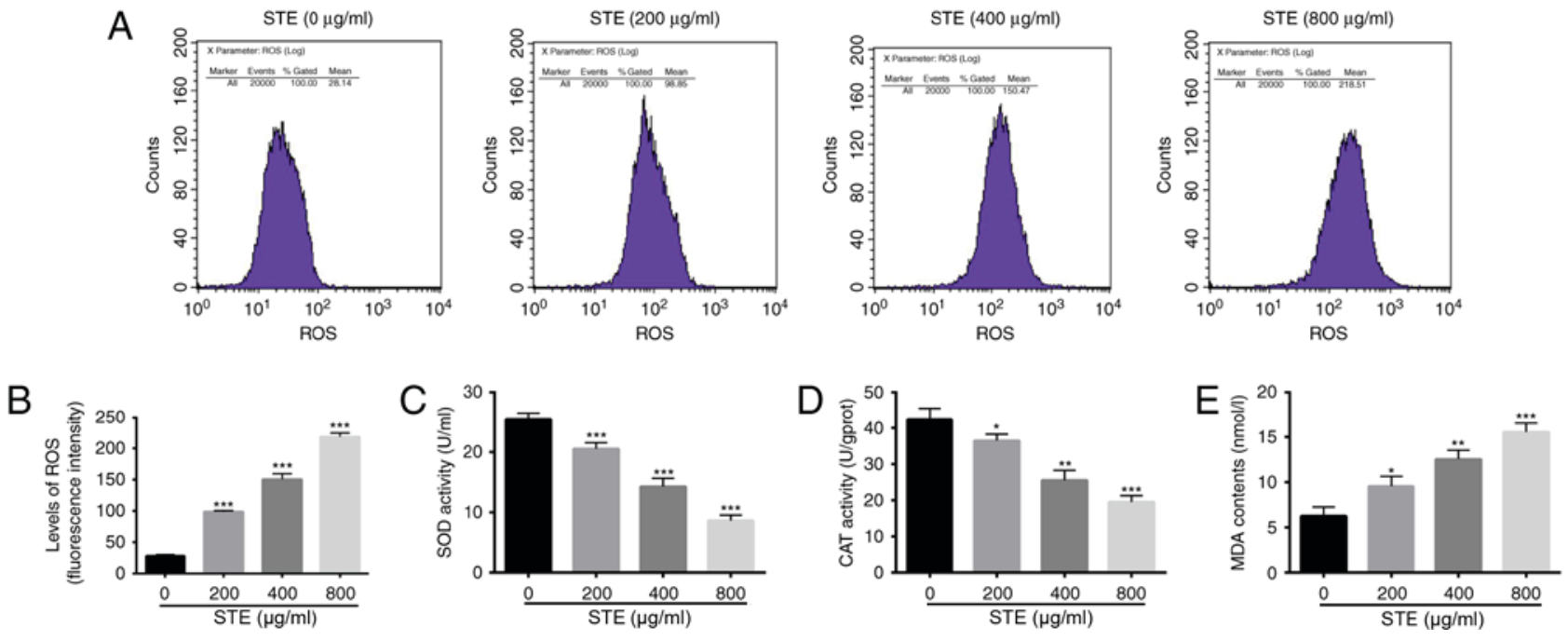

Figure 4. STE increases the concentrations of ROS and MDA and decreases the concentrations of SOD and CAT. Human oral mucosa fibroblasts cells were treated with STE $(0,200,400$ and $800 \mu \mathrm{g} / \mathrm{ml})$ for $48 \mathrm{~h}$. (A) Flow cytometry was used to analyze the concentration of ROS with DCFH-DA fluorescent probe. The representative results of DCF-derived fluorescence are presented. (B) The fluorescence intensity was quantitatively analyzed using the fold change $\left({ }^{* * *} \mathrm{P}<0.001\right.$ vs. $\left.0 \mu \mathrm{g} / \mathrm{ml}\right)$. (C) SOD activity was detected using a commercial kit $\left({ }^{* * *} \mathrm{P}<0.001 \mathrm{vs} .0 \mu \mathrm{g} / \mathrm{ml}\right)$. (D) CAT activity was measured using a CAT activity assay kit $\left({ }^{*} \mathrm{P}<0.05,{ }^{* *} \mathrm{P}<0.01\right.$ and ${ }^{* * *} \mathrm{P}<0.001$ vs. $\left.0 \mu \mathrm{g} / \mathrm{ml}\right)$. (E) MDA activity was analyzed using a MDA activity assay kit $\left({ }^{*} \mathrm{P}<0.05,{ }^{* *} \mathrm{P}<0.01\right.$ and ${ }^{* * *} \mathrm{P}<0.001 \mathrm{vs}$. $0 \mu \mathrm{g} / \mathrm{ml})$. STE, smokeless tobacco extracts; ROS, reactive oxygen species; MDA, malondialdehyde; SOD, superoxide dismutase; CAT, catalase.
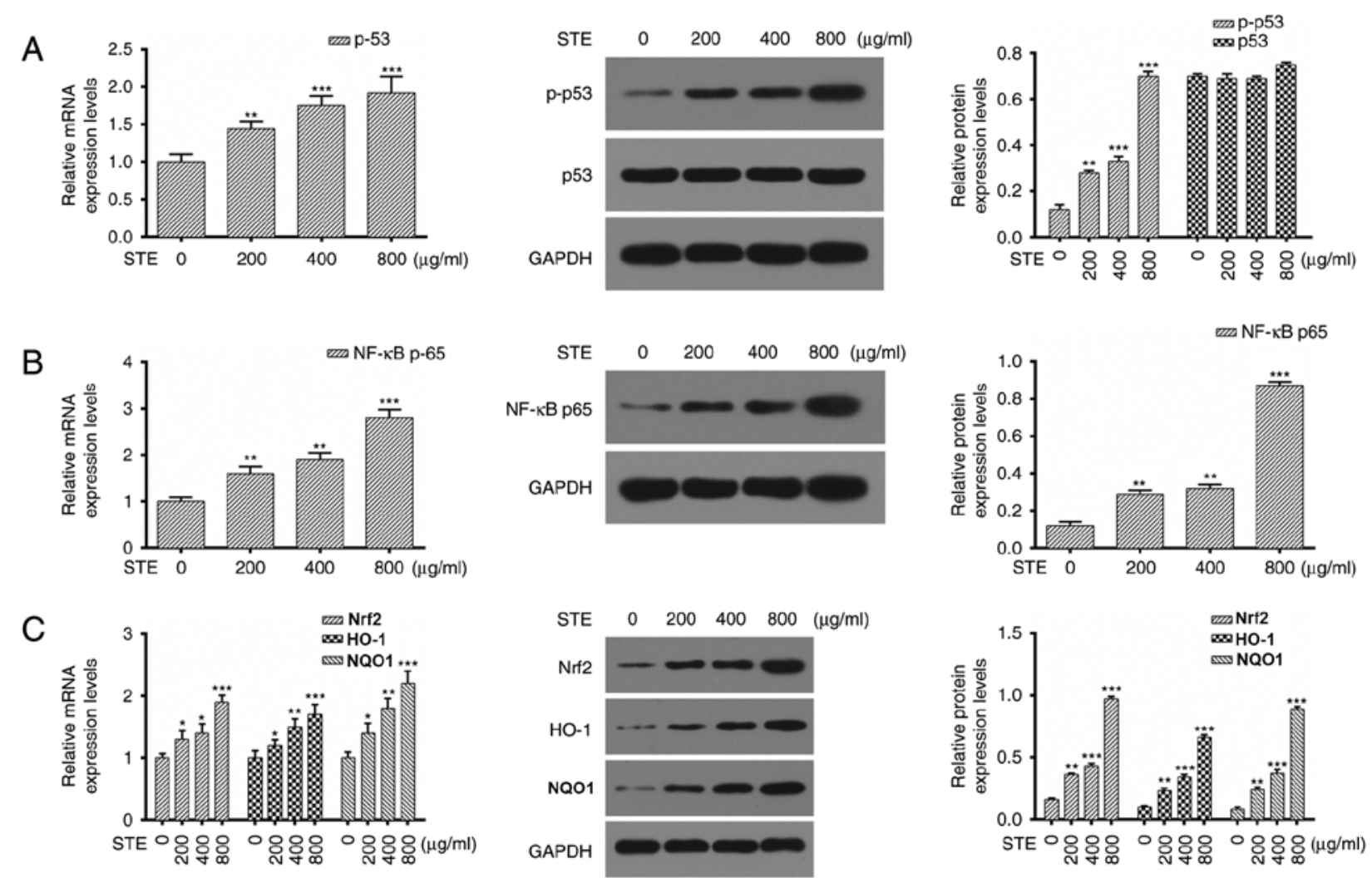

Figure 5. STE upregulates p-p53, NF- $\mathrm{kB}$ p65, Nrf2, HO-1 and NQO1 expression levels in hOMF cells. hOMF cells were treated with STE (0, 200, 400 and $800 \mu \mathrm{g} / \mathrm{ml}$ ) for $48 \mathrm{~h}$ respectively. (A) p53 expression was detected by RT-qPCR and western blot analysis and GAPDH was used as an internal reference $\left({ }^{* * *} \mathrm{P}<0.01\right.$ and ${ }^{* * * *} \mathrm{P}<0.001$ vs. $\left.0 \mu \mathrm{g} / \mathrm{ml}\right)$. (B) RT-qPCR and western blot analysis of NF- $\mathrm{kB}$ p65 in hOMF cells $\left({ }^{* * *} \mathrm{P}<0.01\right.$ and $\left.{ }^{* * * *} \mathrm{P}<0.001 \mathrm{vs} .0 \mu \mathrm{g} / \mathrm{ml}\right) .(\mathrm{C}) \mathrm{Levels}$ of Nrf2, HO-1 and NQO1 were measured by RT-qPCR and western blot analysis ( $\mathrm{P}<0.05,{ }^{* *} \mathrm{P}<0.01$ and ${ }^{* * *} \mathrm{P}<0.001$ vs. $\left.0 \mu \mathrm{g} / \mathrm{ml}\right)$. hOMF, human oral mucosa fibroblasts; STE, smokeless tobacco extracts; p53, tumor protein 53; p, phosphorylated p53; NF- $\mathrm{kB}$, nuclear factor kappa light chain enhancer of activated B cells, p65, transcription factor p65; Nrf2, Nuclear factor (erythroid-derived 2)-like 2; HO-1, Hemeoxygenase 1; NQO1, NAD(P)H quinone dehydrogenase 1; RT-qPCR, reverse transcription quantitative polymerase chain reaction.

that STE treatment increased the expression level of NF- $\kappa \mathrm{B}$ p65 in the hOMF cells in a dose-dependent manner (Fig. 5B). The
Nrf2, HO-1 and NQO1 expression levels were upregulated in the STE treatment group compared with $0 \mu \mathrm{g} / \mathrm{ml}$ (Fig. 5C). 


\section{Discussion}

The use of tobacco remains a major public health concern in a number of countries, due to its established associations with a number of diseases and nicotine addiction $(35,36)$. The nicotine within tobacco is the primary psychoactive substance, and the major source of alkaloids $(37,38)$. Previous studies have identified that tobacco contains a variety of toxic substances, including polycyclic aromatic hydrocarbons, nitrosamines, nicotine, formaldehyde and hydrogen (39). The use of general tobacco may result in a variety of oral diseases, including oral inflammation, oral injury and Snuff dipper's lesions $(40,41)$. Previous studies also have indicated that smokeless tobacco causes other diseases, including peripheral vascular disease, cardiovascular disease, hypertension and increased fetal morbidity and mortality (42). In the present study, the effect of STE on hOMF cells over a range of concentrations and time intervals was explored, in order to identify the potential pathogenic mechanism of STE.

Previous studies have indicated that $\mathrm{p} 21$ was present in several biological progresses and served as a negative regulator of cell proliferation (43). An association between poor prognosis and an accumulation of nuclear p21 in oral squamous cell carcinoma (OSCC) was demonstrated (44). A number of studies also indicated that STE affected the cell proliferation and cell cycle in OSCC $(45,46)$. STE promoted NF- $\mathrm{kB}$ expression and the expression levels of cell cycle-associated proteins p53 and p21 in premalignant lesions in the oral cavity $(47,48)$. The results of the present study indicated that STE significantly inhibited cell proliferation and induced G1-S cell cycle progression in the hOMF cells. It was also identified that STE increased p21 expression and decreased cyclin D1 expression in the hOMF cells.

Apoptosis is a gene-controlled cell-independent death process, which is an important mechanism for the maintenance of a stable internal environment. Apoptosis serves an important role of normal biological function (49,50). Previous studies have indicated that STE may lead to the apoptosis of multiple cell types, including hamster cheek pouch cells, Epstein-Barr virus-infected B cells and oral keratinocytes (51-54). Bcl-2 and Bax proteins are the 2 primary members of apoptosis pathway (55). Bcl-2 serves an anti-apoptotic role, and the Bax protein is similar to the $\mathrm{Bcl}-2$ in structure, but serves an antagonistic role to that of Bcl-2 (56). The molecular mechanisms of STE-induced apoptosis are not fully understood in hOMF cells. The present study identified that the percentage of apoptotic cells was significantly increased subsequent to treatment of the hOMF cells with STE in a dose dependent manner. In addition, Bax expression levels were increased and $\mathrm{Bcl}-2$ levels were decreased in the hOMF cells treated with STE in a dose-dependent manner. The present study indicated that the ROS were chemically reactive molecules containing oxygen, which may induce apoptosis. The results of the present study also revealed that STE increased the concentrations of ROS, and that ROS was closely associated with MDA, SOD and CAT.

$\mathrm{NF}-\mathrm{\kappa B}$ is a nuclear transcription factor that regulates the expression of various genes that are critical for the regulation of apoptosis, inflammation, viral replication, tumorigenesis and various autoimmune diseases (57). Nrf2 is a transcription factor activated by oxidative stress that binds to the antioxidant response element (ARE) (58). ARE-associated genes may participate in the maintenance of redox homeostasis through the activation of proteins, including HO-1 and NQO1 (58). In the present study, it was identified that STE increased the expression level of NF- $\mathrm{KB}$ p65 in the hOMF cells in a dose-dependent manner, and the levels of Nrf2, HO-1 and NQO1 expression were upregulated in the STE treatment group.

In the present study, the potential roles that STE serves in proliferation, cell cycle and apoptosis of hOMF cells were identified. The results indicated that STE increased the rate of cell cycle progression and apoptosis via cell cycle- and apoptosis-associated proteins. STE increased the concentrations of ROS and MDA, decreased the concentrations of SOD and CAT and upregulatedp-p53, NF- $\mathrm{kB}, \mathrm{p} 65$, Nrf2, HO-1 and NQO1 expression levels in hOMF cells.

\section{Acknowledgements}

Not applicable.

\section{Funding}

Not funding was received.

\section{Availability of data and materials}

All data generated or analyzed during this study are included in this published article.

\section{Authors' contributions}

LL and XZ designed the experimental scheme. YW analyzed and interpreted data. LL was a major contributor in writing the manuscript. All authors read and approved the final manuscript.

\section{Ethics approval and consent to participate}

Not applicable.

\section{Patient consent for publication}

Not applicable.

\section{Competing interests}

The authors declare that they have no competing interests.

\section{References}

1. Boffetta P, Hecht S, Gray N, Gupta P and Straif K: Smokeless tobacco and cancer. Lancet Oncol 9: 667-675, 2008.

2. Chagué F, Guenancia C, Gudjoncik A, Moreau D, Cottin Y and Zeller M: Smokeless tobacco, sport and the heart. Arch Cardiovasc Dis 108: 75-83, 2015.

3. England LJ, Kim SY, Tomar SL, Ray CS, Gupta PC, Eissenberg T, Cnattingius S, Bernert JT, Tita AT, Winn DM, et al: Non-cigarette tobacco use among women and adverse pregnancy outcomes. Acta Obstet Gynecol Scand 89: 454-464, 2010.

4. Bates C, Fagerström K, Jarvis MJ, Kunze M, McNeill A and Ramström L: European Union policy on smokeless tobacco: A statement in favour of evidence based regulation for public health. Tob Control 12: 360-367, 2003. 
5. McAdam K, Kimpton H, Vas C, Rushforth D, Porter A and Rodu B: The acrylamide content of smokeless tobacco products. Chem Cent J 9: 56, 2015.

6. Janbaz KH, Qadir MI, Basser HT, Bokhari TH and Ahmad B Risk for oral cancer from smokeless tobacco. Contemp Oncol (Pozn) 18: 160-164, 2014.

7. Lee CH, Lee JM, Wu DC, Hsu HK, Kao EL, Huang HL, Wang TN, Huang MC and Wu MT: Independent and combined effects of alcohol intake, tobacco smoking and betel quid chewing on the risk of esophageal cancer in Taiwan. Int J Cancer 113: 475-482, 2005.

8. Znaor A, Brennan P, Gajalakshmi V, Mathew A, Shanta V, Varghese $C$ and Boffetta P: Independent and combined effects of tobacco smoking, chewing and alcohol drinking on the risk of oral, pharyngeal and esophageal cancers in Indian men. Int J Cancer 105: 681-686, 2003.

9. Brinton LA, Blot WJ, Becker JA, Winn DM, Browder JP, Farmer JC Jr and Fraumeni JF Jr: A case-control study of cancers of the nasal cavity and paranasal sinuses. Am J Epidemiol 119: 896-906, 1984

10. Johansson SL, Hirsch JM, Larsson PA, Saidi J and Osterdahl BG: Snuff-induced carcinogenesis: Effect of snuff in rats initiated with 4-nitroquinoline $\mathrm{N}$-oxide. Cancer Res 49 : 3063-3069, 1989.

11. Lam E, Kelley E, Martin S and Buettner G: Tobacco xenobiotics release nitric oxide. Tob Induc Dis 1: 207-211, 2003

12. Stich HF, Parida BB and Brunnemann KD: Localized formation of micronuclei in the oral mucosa and tobacco-specific nitrosamines in the saliva of 'reverse' smokers, Khainitobacco chewers and gudakhu users. Int J Cancer 50: 172-176, 1992.

13. Hecht SS, Rivenson A, Braley J, DiBello J, Adams JD and Hoffmann D: Induction of oral cavity tumors in F344 rats by tobacco-specific nitrosamines and snuff. Cancer Res 46 : 4162-4166, 1986

14. Rivenson A, Hoffmann D, Prokopczyk B, Amin S and Hecht SS: Induction of lung and exocrine pancreas tumors in F344 rats by tobacco-specific and Areca-derived N-nitrosamines. Cancer Res 48: 6912-6917, 1988.

15. Hecht SS: Biochemistry, biology, and carcinogenicity of tobacco-specific N-nitrosamines. Chem Res Toxicol 11: 559-603, 1998.

16. Patel BP, Rawal UM, Shah PM, Prajapati JA, Rawal RM, Dave TK and Patel PS: Study of tobacco habits and alterations in enzymatic antioxidant system in oral cancer. Oncology 68: 511-519, 2005

17. Naga Sirisha CV and Manohar RM: Study of antioxidant enzymes superoxide dismutase and glutathione peroxidase levels in tobacco chewers and smokers: A pilot study. J Cancer Res Ther 9: 210-214, 2013.

18. Sugiura T, Dohi Y, Takase H, Yamashita S, Fujii S and Ohte N Oxidative stress is closely associated with increased arterial stiffness, especially in aged male smokers without previous cardiovascular events: A cross-sectional study. J Atheroscler Thromb 24: 1186-1198, 2017.

19. Ermis B, Ors R, Yildirim A, Tastekin A, Kardas F and Akcay F: Influence of smoking on maternal and neonatal serum malondialdehyde, superoxide dismutase, and glutathione peroxidase levels. Ann Clin Lab Sci 34: 405-409, 2004.

20. Block G, Dietrich M, Norkus EP, Morrow JD, Hudes M, Caan B and Packer L: Factors associated with oxidative stress in human populations. Am J Epidemiol 156: 274-285, 2002.

21. Harris AC, Tally L, Schmidt CE, Muelken P, Stepanov I, Saha S, Vogel RI and LeSage MG: Animal models to assess the abuse liability of tobacco products: Effects of smokeless tobacco extracts on intracranial self-stimulation. Drug Alcohol Depend 147: 60-67, 2015

22. Yu C, Zhang Z, Liu Y, Zong Y, Chen Y, Du X, Chen J, Feng S, $\mathrm{Hu}$ J, Cui S and Lu G: Toxicity of smokeless tobacco extract after 184-day repeated oral administration in rats. Int J Environ Res Public Health 13: pii: E281, 2016.

23. Avti PK, Vaiphei K, Pathak CM and Khanduja KL: Involvement of various molecular events in cellular injury induced by smokeless tobacco. Chem Res Toxicol 23: 1163-1174, 2010.

24. Avti PK, Kumar S, Pathak CM, Vaiphei K and Khanduja KL: Smokeless tobacco impairs the antioxidant defense in liver, lung, and kidney of rats. Toxicol Sci 89: 547-553, 2006.

25. Livak KJ and Schmittgen TD: Analysis of relative gene expression data using real-time quantitative PCR and the 2(-Delta Delta C(T)) method. Methods 25: 402-408, 2001.
26. Li CJ: Flow cytometry analysis of cell cycle and specific cell synchronization with butyrate. Methods Mol Biol 1524: 149-159, 2017.

27. Filby A, Day W, Purewal S and Martinez-Martin N: The analysis of cell cycle, proliferation, and asymmetric cell division by imaging flow cytometry. Methods Mol Biol 1389: 71-95, 2016.

28. Zhang W and Liang Z: Comparison between annexin V-FITC/PI and Hoechst33342/PI double stainings in the detection of apoptosis by flow cytometry. Xi Bao Yu Fen Zi Mian Yi Xue Za Zhi 30: 1209-1212, 2014 (In Chinese).

29. Shen Y, Guo W, Wang Z, Zhang Y, Zhong L and Zhu Y: Protective effects of hydrogen sulfide in hypoxic human umbilical vein endothelial cells: A possible mitochondria-dependent pathway. Int J Mol Sci 14: 13093-13108, 2013.

30. McCord JM and Fridovich I: Superoxide dismutase. An enzymic function for erythrocuprein (hemocuprein). J Biol Chem 244: 6049-6055, 1969

31. Archbald RM: Enzymatic methods in amino acid analysis. Ann N Y Acad Sci 47: 181-186, 1946.

32. Cheng C, Yi J, Wang R, Cheng L, Wang Z and Lu W: Protection of Spleen Tissue of $\gamma$-ray irradiated mice against immunosuppressive and oxidative effects of radiation by adenosine 5'-monophosphate. Int J Mol Sci 19: pii: E1273, 2018.

33. Simon HU, Haj-Yehia A and Levi-Schaffer F: Role of reactive oxygen species (ROS) in apoptosis induction. Apoptosis 5: 415-418, 2000

34. Yee $\mathrm{C}$, Yang $\mathrm{W}$ and Hekimi $\mathrm{S}$ : The intrinsic apoptosis pathway mediates the pro-longevity response to mitochondrial ROS in C. elegans. Cell 157: 897-909, 2014.

35. Napierala M and Florek E: Historical trends in prevalence of tobacco smoking among women. Przegl Lek 72: 155-157, 2015 (In Polish).

36. Weintraub JM and Hamilton WL: Trends in prevalence of current smoking, Massachusetts and states without tobacco control programmes, 1990 to 1999. Tob Control 11 (Suppl 2): ii8-ii13, 2002.

37. Corrigall WA: Nicotine self-administration in animals as a dependence model. Nicotine Tob Res 1: 11-20, 1999.

38. Rose JE and Corrigall WA: Nicotine self-administration in animals and humans: Similarities and differences. Psychopharmacology (Berl) 130: 28-40, 1997.

39. Schick SF,Farraro KF,Perrino C,Sleiman M, van de Vossenberg G, Trinh MP, Hammond SK, Jenkins BM and Balmes J: Thirdhand cigarette smoke in an experimental chamber: Evidence of surface deposition of nicotine, nitrosamines and polycyclic aromatic hydrocarbons and de novo formation of NNK. Tob Control 23: $152-159,2014$.

40. Furukawa S, Ueno M and Kawaguchi Y: Influence of tobacco on dental and oral diseases. Nihon Rinsho 71: 459-463, 2013 (In Japanese).

41. Didilescu A: Tobacco induced oral diseases. Pneumologia 49: 300-303, 2000 (In Romanian).

42. Critchley JA and Unal B: Health effects associated with smokeless tobacco: A systematic review. Thorax 58: 435-443, 2003.

43. Gartel AL, Serfas MS and Tyner AL: p21-negative regulator of the cell cycle. Proc Soc Exp Biol Med 213: 138-149, 1996.

44. Huang KJ, Kuo CH, Chen SH, Lin CY and Lee YR: Honokiol inhibits in vitro and in vivo growth of oral squamous cell carcinoma through induction of apoptosis, cell cycle arrest and autophagy. J Cell Mol Med 22: 1894-1908, 2018.

45. Mishra R and Das BR: Activation of STAT 5-cyclin D1 pathway in chewing tobacco mediated oral squamous cell carcinoma. Mol Biol Rep 32: 159-166, 2005

46. Mishra R and Das BR: Cyclin D1 expression and its possible regulation in chewing tobacco mediated oral squamous cell carcinoma progression. Arch Oral Biol 54: 917-923, 2009.

47. Rohatgi N, Kaur J, Srivastava A and Ralhan R: Smokeless tobacco (khaini) extracts modulate gene expression in epithelial cell culture from an oral hyperplasia. Oral Oncol 41: 806-820, 2005.

48. Sawhney M, Rohatgi N, Kaur J, Shishodia S, Sethi G, Gupta SD, Deo SV, Shukla NK, Aggarwal BB and Ralhan R: Expression of NF-kappaB parallels COX-2 expression in oral precancer and cancer: Association with smokeless tobacco. Int J Cancer 120: 2545-2556, 2007.

49. Jiang $\mathrm{P}$ and Yue Y: Human papillomavirus oncoproteins and apoptosis (Review). Exp Ther Med 7: 3-7, 2014 
50. Ni Nyoman AD and Lüder CG: Apoptosis-like cell death pathways in the unicellular parasite Toxoplasma gondii following treatment with apoptosis inducers and chemotherapeutic agents: A proof-of-concept study. Apoptosis 18: 664-680, 2013.

51. Bagchi M, Balmoori J, Bagchi D, Ray SD, Kuszynski C and Stohs SJ: Smokeless tobacco, oxidative stress, apoptosis, and antioxidants in human oral keratinocytes. Free Radic Biol Med 26: 992-1000, 1999

52. Jenson HB, Baillargeon J, Heard P and Moyer MP: Effects of smokeless tobacco and tumor promoters on cell population growth and apoptosis of B lymphocytes infected with epstein-barr virus types 1 and 2. Toxicol Appl Pharmacol 160: 171-182, 1999.

53. Mangipudy RS and Vishwanatha JK: Role of nitric oxide in the induction of apoptosis by smokeless tobacco extract. Mol Cell Biochem 200: 51-57, 1999.

54. Banerjee AG, Gopalakrishnan VK and Vishwanatha JK Inhibition of nitric oxide-induced apoptosis by nicotine in oral epithelial cells. Mol Cell Biochem 305: 113-121, 2007.

55. Kuwana T and Newmeyer DD: Bcl-2-family proteins and the role of mitochondria in apoptosis. Curr Opin Cell Biol 15: 691-699, 2003.
56. Breckenridge DG and Xue D: Regulation of mitochondrial membrane permeabilization by BCL-2 family proteins and caspases. Curr Opin Cell Biol 16: 647-652, 2004.

57. Panday A, Inda ME, Bagam P, Sahoo MK, Osorio D and Batra S: Transcription factor NF- $\kappa$ B: An update on intervention strategies. Arch Immunol Ther Exp (Warsz) 64: 463-483, 2016.

58. Jaiswal AK: Nrf2 signaling in coordinated activation of antioxidant gene expression. Free Radic Biol Med 36: 1199-1207, 2004.

This work is licensed under a Creative Commons Attribution-NonCommercial-NoDerivatives 4.0 International (CC BY-NC-ND 4.0) License. 